\title{
REFLEKSI NILAI-NILAI PENDIDIKAN KI HADJAR DEWANTARA DALAM UPAYA UPAYA MENGEMBALIKAN JATI DIRI PENDIDIKAN INDONESIA
}

\author{
Sigit Vebrianto Susilo \\ sigitvebriantosusilo@unma.ac.id \\ Universitas Majalengka
}

\begin{abstract}
ABSTRAK
Bangsa Indonesia melalui generasi penerus bangsa perlu mewarisi dan merefleksikan kembali buah pemikiran Ki Hadjar Dewantara. Dalam pandangannya, tujuan pendidikan adalah memajukan bangsa secara menyeluruh tanpa membeda-bedakan agama, etnis, suku, budaya, adat, kebiasaan, status ekonomi, status sosial serta didasarkan kepada nilai-nilai kemerdekaan sejati. Dasar-dasar pendidikan Barat dirasakan $\mathrm{Ki}$ Hadjar tidak tepat dan tidak cocok untuk mendidik generasi muda Indonesia karena pendidikan barat bersifat regering, tucht, orde (perintah, hukuman dan ketertiban). Karakter pendidikan semacam ini dalam prakteknya merupakan suatu perkosaan atas kehidupan batin anak-anak. Akibatnya, anak-anak rusak budi pekertinya karena selalu hidup di bawah paksaan/tekanan. Menurut Ki Hadjar, cara mendidik semacam itu tidak akan bisa membentuk seseorang hingga memiliki "kepribadian". Sejalan dengan pandangan ini, pendidikan di Indonesia seyogianya memberikan rasa aman, menyenangkan, tenang, dan memberikan rasa bahagia sehingga siswa tanpa paksaan dan secara alamiah menyantap ilmu pengetahuan dengan maksimal. Di sisi lain, tuntutan hidup abad ke-21 secara makro dan pemberlakuan kurikulum baru di Indonesia secara mikro menuntut pendidikan mampu menghasilkan lulusan yang memiliki kompetensi hidup di abad ke-21. Memasuki abad 21 kemajuan teknologi telah memasuki berbagai sendi kehidupan, termasuk pendidikan. Oleh sebab itu, perlu kiranya sebagai generasi penerus bangsa kembali membedah intisari dari konsep pendidikan menurut Ki Hajar Dewantara dalam pandangan pendidikan multiliterasi. Pendidikan multiliterasi yang memberikan kebebasan siswa dalam berpikir, berkreasi, dan berpendapat sejalan dengan konsep pancadarma yang dikemukakan oleh Ki Hajar Dewantara. Selanjutnya pendidikan multiliterasi memiliki ciri yakni multi konsep, multi budaya, multi gaya belajar, dan multi multi modal memberikan sebuah konsep pendidikan yang memberikan kesan dan mengarahkan kepada nilai-nilai pancasila. Abad ke 21 memberikan sebuah gambaran bahwa pendidikan menjadi semakin penting untuk menjamin peserta didik memiliki keterampilan belajar dan berinovasi, keterampilan menggunakan teknologi dan media informasi, serta dapat bekerja, dan bertahan dengan menggunakan keterampilan untuk hidup (life skills). Sejalan dengan pemaparan di atas, dengan merefleksikan kembali nilai pendidikan Ki Hajar Dewantara dalam perspektif pendidikan multiliterasi merupakan suatu wujud nyata dalam menyongsong pendidikan Indonesia agar kelak Indonesia mampu mewujudkan citacitanya yakni menciptakan generasi emas 2045.
\end{abstract}

Kata Kunci: Pendidikan Ki Hajar Dewantara, Pendidikan Abad Ke-21 


\section{A. Pendahuluan}

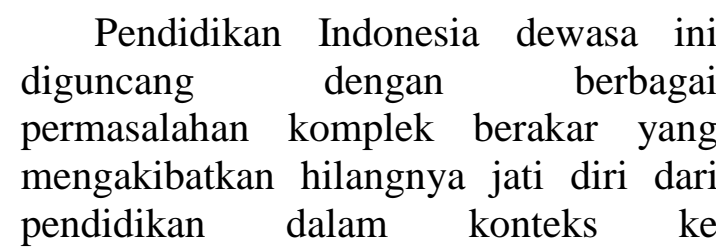
Indonesiaan. Sejumlah fenomena yang terjadi belakangan ini memberikan tamparan keras bagi pelaku pendidikan yang memberikan gambaran boboroknya nilai-nilai dan esensi dari pendidikan itu sendiri. Tujuan pendidikan nasional yang tertera UUD 1945 yakni setiap warganegara berhak memperoleh pendidikan yang paripurna secara manusiawi seakan kehilangan arah orientasi dan tujuannya. Hal ini sejalan dengan pemikiran H.A.R Tilaar dkk. (2011 hal 13) yakni "pendidikan sebagai proses adalah berarti bahwa pendidikan merupakan suatu peristiwa memanusia. Bertemali dengan pendapat Tilaar dkk di atas, pendidikan semestinya mampu memberikan tempat yang nyaman terhadap seluruh pelaku didalamnya sehingga pendidikan akan mampu melahirkan generasi yang bermutu dan bermartabat.

Seiring dengan perkembangan zaman, pendidikan muncul dalam berbagai bentuk dan paham. Dilihat dari sejarahnya, Pendidikan Indonesia dapat dibagi secara urutan waktu kurang lebih sebagai berikut: (a) jaman pra-kolonial: masa prasejarah dan masa sejarah, (b) jaman kolonial ketika sistem pendidikan 'modern' dari Eropa diperkenalkan, dan (c) jaman kemerdekaan RI yang berlangsung hingga sekarang. Masingmasing jaman memiliki corak dan bentuk tersendiri (Rohman \& Wibowo: 2016). Memasuki abad ke-21 sekarang ini, Pendidikan Indonesia dihadapkan dengan sejumlah tantangan dan peluang, yang tentunya berbeda dengan jaman-jaman sebelumnya. Guna mengantisipasi dan menyesuaikan diri dengan berbagai tuntutan dan dinamika perubahan yang sedang dan akan terus berlangsung di Abad ke-21 ini,

H.A.R Tilaar (79: 2012) mengungkapkan bahwa masyarakat dan bangsa Indonesia adalah bagian dari kehidupan global dan oleh sebab itu tidak terlepas dari gelombang perubahan sosial yang terjadi, yaitu proses demokrasi yang di dalamnya termasuk hak asasi manusia, perkembangan yang sangat pesat dari ilmu pengetahuan dan teknologi khususnya teknologi informasi, dan proses globalisasi yang mengena seluruh aspek kehidupan manusia Indonesia. Derasnya arus globalisasi memberikan pengaruh besar bagi perkembangan pendidika Indonesia. Bahkan boleh dikatakan bahwa pendidikan Indonesia hari ini kiblatnya adalah pendidikan yang berkembang di barat. Arus globalisasi dewasa ini telah membatasi fungsi dan hakikat manusia sebagai mahkluk hidup dunia. Andaikata Bapak Pendidikan kita (Ki Hajar Dewantoro) masih hidup, tentu dia akan sedih melihat sistem pendidikan kita yang morat-marit seperti ini. Pendidikan yang seyogyanya sebagai upaya untuk meningkatkan harkat dan martabat bangsa, hanya menjadi isapan jempol. Betapa tidak, ketika negara lain seperti Malaysia, Singapura, dan Thailand lebih memprioritaskan pendidikan sebagai upaya untuk membangun bangsa (nation building), kita malah sebaliknya.

Menurut Nanang Bagus Subekti dalam Harian SindoNews.com tanggal 23 Maret 2015 Pemikiran pendidikan Ki Hadjar Dewantara juga tidak kalah dengan pemikiran dan teori pendidikan modern. Misalnya, Ki Hadjar Dewantara jauh lebih dulu mengenalkan konsep TriNga yang terdiri dari Ngerti (kognitif), Ngrasa (afektif) dan Nglakoni (psikomotorik) dari Taxonomy Bloom (cognitive, affective, psychomotor) yang terkenal. Konsep-konsep $\mathrm{Ki}$ Hadjar Dewantara tersebut diimplementasikan di 
Tamansiswa yang berdiri 3 Juli 1922, sedangkan Taxonomy Bloom dikenalkan pada tahun 1956 oleh Dr Benjamin Bloom. Ini salah satu bukti jika pemikiran Ki Hadjar Dewantara tidak kalah dengan ilmuwan barat.

\section{B. Merefleksi Nilai-Nilai Pendidikan Ki Hajar Dewantara}

Sosok Ki Hajar Dewantara tidak bisa kita lepaskan dari perjalanan panjang pendidikan Indonesia. Ki Hajar Dewantara merupakan pioner dan pelopor terbentuknya sistem pendidikan di Indonesia. Keberadaannya dalam menentang penjajahan Belanda adalah dengan mendirikan Perguruan Taman Siswa. Dengan mendirikan perguruan tersebut ia bercita-cita agar bangsa Indonesia merdeka lahir batin. Pemikirannya sangat relevan sebagai sebuah terobosan dalam membangun pendidikan saat ini yang dalam keadaan kritis. Semboyannya yang terkenal ialah tut wuri handayani (di belakang memberi dorongan), ing madya mangun karsa (di tengah menciptakan peluang untuk berprakarsa), ing ngarsa sung tulada (di depan memberi teladan). Bagian depan dari semboyannya, tut wuri handayani, menjadi slogan Departemen Pendidikan Nasional (Dewantara, Ki Hajar 1977.hal.215.)

Ketiga semboyan ini apabila kita maknai serta hayati bersama merupakan akar dan ujung tombak dari peran serta guru dalam menjalankan roda pendidikan nasional. Semboyan ini sejalan dengan yang diutarakan oleh Abidin (2015) bahwa tugas dan fungsi guru didalam kelas tidak hanya transfer knowladge, melainkan inti dari tugas guru adalah mengembangkan, mengarahkan, dan memberimotifasi. Makna ing ngarsa sung tulada (di depan memberi teladan) seyogianya dimaknai sebagai guru mampu memberikan contoh yang baik dalam berbagai dimensi. Sifat, perilaku, penampilan, tutur kata, sopan santun dan lain sebagainya dalam hal ini adalah bagian dari suatu paket yang harus guru contohkan. Pepatah mengatakan bahwa "guru kencing berdiri, maka siswa kencing berlari. Jadi apabila fenomena hari ini menunjukan bobroknya mental di kalangan pelajar kita, maka sepatutnya kita merefleksikan kepada diri kita apakah kita sudah benar-benar memberikan contoh yang baik bagi siswa. Sebab faktanya pendidikan negeri ini belakangan banyak diguncang dan dhadapkan pada kasuskasus seperti asusila, kekerasan, narkotika, tawuran, bullying, dan masih banyak lagi sederet cerita panjang betapa lembaga pendidikan kita hari ini sering sekali dirundung duka. Semboyan berikutnya adalah ing madya mangun karsa (di tengah menciptakan peluang untuk berprakarsa). Menurut pandangan penulis guru hari ini tidak zaman nya lagi untuk gengsi bercengkrama dengan siswa. Apalagi menunjukan sikap membatasi diri dan menganggap siswa adalah sosok makhluk yang lebih rendah daripada gurunya. Semboyan ini memberikan rambu-rambu kepada kita bahwa sebagai guru harus mampu ampil sebagai sosok teman atau sahabat yang baik ditengah-tengah siswa. Apalagi apabila kita berbicara mengenai pendidikan dasar atau lebih spesifik kepada pendidikan sekolah dasar. Anakanak terkadang jauh lebih peka dibandingkan dengan orang dewasa. Anakanak adalah peniru/imitator ulung. Apa yang dia lihat dan dia dengan apalagi apabila muncul dari sosok yang bisa dikatakan dijadikan sebagai panutan, maka apapun yang keluar dari sosok panutan itu adalah akan dijadikan sebagai acuan. Berikutnya adalah tut wuri handayani, tentunya selayaknya seorang guru harus senantiasa memberikan motivasi positif kepada seluruh siswanya. Hakikatnya manusia mempunyai kebutuhan lain, yakni salah satunya adalah motivasi. Guru harus mampu membangkitkan semangat dan gairah siswa demi mewujudkan asa dan 
cita-citanya. Artinya bahwa seorang guru seyogianya mampu memberikan stimulusstimulus positif kepada siswa sesuai dengan minat dan kebutuhan siswa. Guru membantu siswa untuk menemukan, mengembangkan dan mencoba mempraktikkan kemampuankemampuan yang mereka miliki (the learners-centered teaching).

Dalam berbagai penjelasannya $\mathrm{Ki}$ Hajar memandang siswa atau peserta didik adalah manusia yang mempunyai kodratnya sendiri dan juga kebebasan dalam menentukan hidupnya. Pandangan $\mathrm{Ki}$ Hajar tentang siswa yang tidak mengekang kebebasan siswa ini sesuai dengan pandangan humanistik terhadap siswa. Aliran humanistik ini membantu siswa dalam mengembangkan potensinya dan membiarkan siswa belajar dari pengalaman yang dialaminya sendiri.

Ki Hajar Dewantara terkenal juga sebagai pejuang dan budayawan. Selanjutnya dalam konteks pendidikan, Ki Hajar Dewantara mengemukakan Panca Dharma. Panca Dharma secara umum berarti "lima asas". Lima asas pemikiran yang terhimpun dalam konsepsi tersebut adalah: asas kodrat alam, asas kemerdekaan, asas kebudayaan, asas kebangsaan, dan asas kemanusiaan (Solehan: 2010).

Pancadarma memberikan sebuah gambaran dengan sendirinya mendorongkan asas aliran, haluan, anjuran, tekat, niat, dan kemauan supaya kita bisa berbuat segala apa yang berdasarkan lima dasar itu. Tentang urutan-urutan lima dasar tersebut, menurutnya tidak harus memakai urutan yang pasti atau tertentu. Sebaiknya hal ini diseseuaikan dengan caranya kita menggambarkan dasar-dasar dan asas-asas itu, misalnya sebagai yang berikut: Berilah (Kemerdekaan) dan kebebasan kepada anak-anak kita; bukan kemerdekaan yang leluasa. Namun yang terbatas oleh tuntutantuntutan (Kodrat alam) yang hak atau nyata, dan menuju ke arah (Kebudayaan), yakni keluhuran dan kehalusan hidup manusia. Agar kebudayaan tadi dapat menyelamatkan dan membahagiakan hidup dan penghidupan diri dan masyarakat, maka perlulah dipakainya dasar (Kebangsaan), akan tetapi jangan sekalikali dasar ini melanggar atau bertentangan dengan dasar yang lebih luas, yaitu dasar (Kemanusiaan). Dewantara, Ki Hadjar. (1964). Asas-asas dan Dasar-dasar Tamansiswa,Yogyakarta: Majlis Luhur Tamaniswa.

$$
\text { Selanjutnya Ing Ngarso Sung }
$$

Tulodo, Ing Madyo Mangun Karso, Tutwuri Handayani adalah kalimat yang mungkin sudah tidak asing bagi kita. Dalam dunia pendidikan slogan ini dijadikan sebagai sebuah logo oleh Kementerian Pendidikan dan Kebudayaan di tanah air. Slogan yang diciptakan oleh Ki Hajar Dewantara ini mempunyai makna yang sangat mendalam bagi pendidikan. Secara harfiah Tut Wuri berarti mengikuti dari belakang, Handayani mengandung arti memberi semangat motivasi dan moral. Secara lengkap slogan tersebut berarti di depan memberikan contoh, di tengah memberi semangat, di belakang memberi dorongan. Jika diinterpretasikan slogan ini mengandung makna bahwa siorang guru harus memberikan dorongan, contoh dan menciptakan kreativitas terhadap anak didiknya.

Dari sudut pandang isinya, pendidikan yang digagas oleh $\mathrm{Ki}$ Hadjar Dewantara memiliki kriteria-kriteria yang secara eksplisit mengandung enam unsur, yaitu: 1) pendidikan kebebasan (merdeka), 2) pendidikan kemanusiaan (humanisme), 3) pendidikan spiritual (kodrat alam), 4) pendidikan budi pekerti, 5) pendidikan sosial (kekeluargaan) dan 6) pendidikan kepemimpinan (Tut Wuri Handayani) (Muthoifin: 2015). Bahkan, berbagai aspek yang terkait dengan pendidikan seperti visi, misi, tujuan, kurikulum, metode, dan tahapan pendidikan lainnya harus dirumuskan berdasarkan kemauan bangsa Indonesia yang berasal dari berbagai suku, 
etnis, dan budaya yang beraneka ragam. Sehingga gagasan dan pemikiran dari $\mathrm{Ki}$ Hadjar inilah yang kemudian menjadi acuan penyelenggaraan pendidikan nasional hingga sekarang ini. Apalagi gagasan dan pemikiran pendidikan $\mathrm{Ki}$ Hadjar yang sudah ditulis dalam berbagai karangannya, mendapat sambutan hangat dari Presiden Republik Indonesia pertama Ir. Soekarno. Sebagaimana gagasan tentang prinsip pendidikan yang berbunyi Ing ngarso sung tulodo, Ing madya mangun karso, Tut wuri handayani adalah berasal dari buah pemikirannya. Begitu juga konsep Sistem Among (sistem pengajaran) dan Kodrat Alam (kehendak alam) juga merupakan buah gagasan dari pemikirannya. Bapak Pendidikan Nasional Ki Hajar Dewantara merangkum konsep yang dikenal dengan istilah Among Methode atau sistem among. Among mempunyai pengertian menjaga, membina dan mendidik anak dengan kasih sayang. Pelaksana "among" (momong) disebut Pamong, yang mempunyai kepandaian dan pengalaman lebih dari yang diamong. Guru atau dosen di Taman Siswa disebut pamong yang bertugas mendidik dan mengajar anak sepanjang waktu. Tujuan sistem among membangun anak didik menjadi manusia beriman dan bertakwa, merdeka lahir batin, budi pekerti luhur, cerdas dan berketerampilan, serta sehat jasmani rohani agar menjadi anggota masyarakat yang mandiri dan bertanggung jawab atas kesejahteraan tanah air serta manusia pada umumnya. (Dwiarso: 2012.)

Sistem Among adalah suatu sistem pendidikan yang berjiwa kekeluargaan yang bersendikan kodrat alam dan kemerdekaan. Sistem Among ini berdasarkan cara berlakunya disebut sistem Tut wuri Handayani. Dalam sistem ini orientasi pendidikan adalah pada anak didik, yang dalam terminologi baru disebut student centered. Sedangkan Kodrat alam, menurut Ahmad Sholeh dalam bukunya berjudul Relevansi Gagasan Sistem Among dan Tri Pusat Pendidikan Ki Hadjar Dewantara terhadap Pengembangan Pendidikan Islam di Indonesia, adalah perwujudan dari kekuasaan Tuhan yang mengandung arti, bahwa pada hakekatnya manusia sebagi mahluk Tuhan adalah satu dengan alam lain.

\section{Taman siswa: "sebuah tawaran sistem pendidikan Ki Hadjar untuk Indonesia"}

Bangsa dan Negara ini perlu mewarisi buah pemikiran $\mathrm{Ki}$ Hadjar Dewantara. Menurut persepsinya, tujuan pendidikan adalah memajukan bangsa secara keseluruhan tanpa membedabedakan agama, etnis, suku, budaya, adat, kebiasaan, status ekonomi, status sosial serta didasarkan kepada nilai-nilai kemerdekaan yang asasi. Dasar-dasar pendidikan barat dirasakan Ki Hadjar tidak tepat dan tidak cocok untuk mendidik generasi muda Indonesia karena pendidikan barat bersifat regering, tucht, orde (perintah, hukuman dan ketertiban). Karakter pendidikan semacam ini dalam prakteknya merupakan suatu perkosaan atas kehidupan batin anak-anak. Akibatnya, anak-anak rusak budi pekertinya karena selalu hidup di bawah paksaan/tekanan. Menurut Ki Hadjar, cara mendidik semacam itu tidak akan bisa membentuk seseorang hingga memiliki "kepribadian".(Dewantara, Ki Hadjar. 1962. Karja I (Pendidikan). Pertjetakan Taman Siswa, Jogjakarta, hal. 14-15.)

\section{Pendidikan Abad Ke-21: Pegembangan Konsep Pendidikan Ki Hadjar Dewantara}

Sejalan dengan perkembangan dan kemajuan dunia dalam berbagai sector, pendidikan mempunyai pranan penting dalam pergerakannya. Seiring dengan arus globalisasi serta kemajuan ilmu pengetahuan dan teknologi, maka dengan ini ditandai dengan semakin meningkatnya kebutuhan manusia. Apabila kita 
perhatikan dengan seksama, manusia sebagai masyarakat dunia seiring dengan berjalannya waktu mengoptimalkan segala kemampuannya untuk memberikan sumbangsi pemikirannya demi terpenuhi kebutuhan hidup dan kehidupannya. Apabila kita ambil contoh, jika dulu manusia ingin berkomunikasi dengan manusia yang lain dengan tempat yang berbeda secara geografis, maka akan membutuhkan proses dan waktu yang lama agar informasi berupa pesan itu akan sampai kepada orang yang dituju. Jika kita bandingkan dengan sekarang, dalam hitungan detik pesan itu akan langsung sampai kepada orang yang dituju. Era digital dan internet menyerbu dunia termasuk tanah air kita menawarkan berbagai kemudahan dengan tingkat efisiensi yang begitu praktis dan cepat. Sejalan dengan perubahan tersebut, maka manusia di tuntut untuk berubah dalam segala aspek. Baik dari kebutuhan, kebiasaan hidup, dan berbagai macam lainya yang erat kaitanya dengan manusia. Dai paparan ilustrasi tadi memberikan kita suatu pandangan bahwa era abad 21 telah bermetamorfosa dalam berbagai sendi kehidupan bermasyarakat. Di abad ke 21 ini, pendidikan menjadi semakin penting untuk menjamin peserta didik memiliki keterampilan belajar dan berinovasi, keterampilan menggunakan teknologi dan media informasi, serta dapat bekerja, dan bertahan dengan menggunakan keterampilan untuk hidup (life skills). Menyikapi perkembangan pendidikan pada abad ke-21, setidaknya ada tiga konsep dalam pendidikan abad ke-21 adalah $21^{\text {st }}$ Century Skills (Trilling dan Fadel, 2009), scientific approach (Dyer, et al., 2009) dan authentic assesment (Wiggins dan McTighe, 2011).

Keterampilan abad 21 adalah (1) life and career skills, (2) learning and innovation skills, dan (3) Information media and technology skills. Ketiga keterampilan tersebut dirangkum dalam sebuah skema yang disebut dengan pelangi keterampilan pengetahuan abad $21 / 21^{\text {st }}$ century knowledge-skills rainbow (Trilling dan Fadel, 2009).

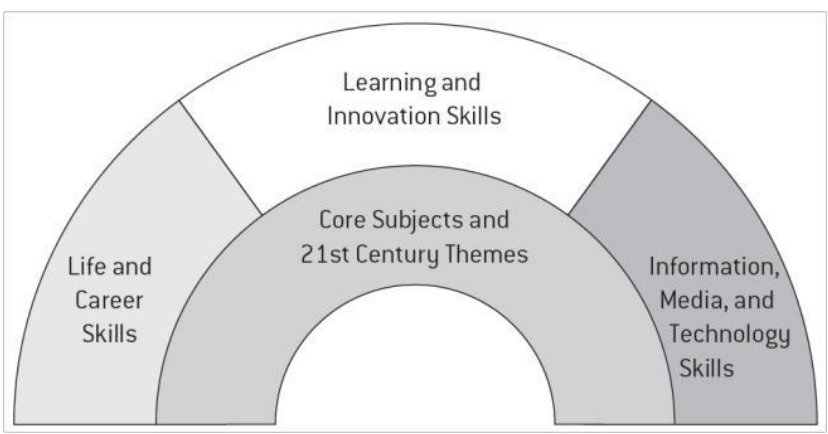

\section{Gambar 1: Pelangi Keterampilan- Pengetahuan Abad 21}

Sumber: Trilling dan Fadel (2009)

Pendidikan pada abad 21 seyogianya dapat membentuk insan manusia menjadi manusia yang kritis dalam iintelektual, kreatif dalam pemikiran, etis dalam pergaulan, dan berkarakter dalam berkehidupan (Abidin: 2015). Artinya bahwa pendidikan pada era abad 21 memacu manusia sebagai actor utama dalam kehidupan di dunia untuk capakat dalam berbagai bidang. Generasi muda masa depan harus mampu tidak lagi bekerja dengan otot, namun harus mampu dengan otak, mengubah paradigma bahwa bekerja tidak hanya cukup mempunyai satu kecakapan, namun multikecakapan/ multidimensional. Atas dasar ini pendidikan segianya mampu menjadi garda terdepan dalam membina dan membentuk insan muda Indonesia mempunyai kemampuan dan kecakapan multidimensional.

Manusia yang cerdas adalah manusia yang berbudaya (H.A.R Tilaar, 149: 2012b). Menurut Ki Hajar Dewantara (1977) mendidik adalah menuntun segala kekuatan kodrat yang ada pada anak-anak agar mereka sebagai manusia dan sebagai anggota masyarakat dapat mencapai keselamatan dan kebahagiaan yang setinggi-tingginya. Pendidikan tanpa 
didasari nilai-nilai budaya local bangsa kita hanya akan menjadikan bangsa kita menjadi bangsa yang selalu mengikuti bangsa orang lain. Sebab budaya kitalah yang akan menjadi pembeda untuk dapat tampil bersandaing dan bersaing dengan negara lain. Budaya kita yang beranekaragam mengajarkan nilai-nilai kebaikan, kesopanan, dan nilai keagamaan. Rasanya jika merujuk dengan poin tadi, jauh dari nuansa kekerasan atau hal-hal yang berbau kriminalitas. Hal ini menunjukan kepada kita bahwa ada korelasi antara nilai-nilai kebudayaan nenek moyang kita terhadap terbentuknya system pendidikan kita hari ini sebelum datang para penjajah (Panjaitan, dkk: 2014).

Merujuk terhadap pendapat Koentjaraningrat (1985) merumuskan tiga gejala kebudayaan diantaranya adalah sebagai berikut:

1. Wujud kebudayaan sebagai suatu kompleks dari ide-ide, gagasan, nilai-nilai, norma-norma, peraturan-peraturan, dan sebagainya.

2. Wujud kebudayaan sebagai suatu komplek aktivitas serta tindakan berpola dari manusia dalam masyarakat

3. Wujud kebudayaan sebagai bendabenda hasil dari manusia

Fungsi pertama pendidikan menurut Metta dkk (Panjaitan, dkk, 24: 2014) ialah transmitting culture. Selanjutnya pendidikan dikaitkan dengan definisi kebudayaan yang dikembangkan adalah culture consist of complex ideas that can be passed from one generation to another only through years of interaction between student and theachers. Metta $\mathrm{dkk}$ berkesimpulan bahwa pendidikan itu terjadi diantara siswa dan guru melaui hubungan interaksi yang berlangsung bertahun-tahun (Panjaitan, dkk, 24: 2014).
Devinisi klasik dari E.B Taylor (Panjaitan, dkk: 2014) bahwa Arts atau seni adalah unsure kebudayaan yang penting, sementara seni dapat dibagi menjadi seni lukis, sastra, arsitektur, tari, seni bertutur indah, dan sebagainya. Seniseni tersebut banyak dimiliki dan siterapkan atau diperagakan masyarakat pemiliknya.didalam seni tersebut banyak nilai budaya yang dapat ditemukan, yang sebenarnya berfungsi pendidikan dan pengajaran.

Kaitannya dengan kebudayaan sebagai dasar atau fundamen atau ruh dari pendidikan Indonesia adalah upaya penyelamatan kebudayaan local agar tetap dimiliki dan digunakan oleh bangsanya. Hari ini banyak anak-anak muda generasi penerus bangsa mengalami degradasi kepercaan diri ketika menggunakan hal-hal yang berbau budaya local. Anggapan kuno, kampungan, dan lainya menjadikan anak-anak muda mengalihkan pandangan mereka kepada sesuau yang mereka anggap trend. Penggunaan alat-alat atau media unutuk sarana penunjang dalam kehidupan memang tidak dipungkiri menjadikan manusia menjadi dan membentuk manusia individualistis yang cenderung egois dan tidak mempedulikan lingkungannya. Seuatu yang harus dilakukan oleh kita sebagai generasi penerus bangsa adalah menanamkan nilainilai budaya local seperti budaya gotongroyong, budaya saling menghormati dan menghargai, budaya toleransi, budaya yang bernuansa religi, budaya yang sesuai nilai dan normna, dan lain sebagainya. Seperti yang diungkapkan oleh H.A.R Tilaar (39: 2007) bahwa dalam membina identitas diri atau jati diri bangsa Indonesia memerlukan upaya yang berkesinambungan serta berkaitan dengan berbagai aspek. Kedudukannya sebagai warga negara Indonesia tidak mengenal diskriminatif, kehidupan bersama yang penuh toleransi dan menghindari berbagai kecurigaan atau dengan yang lain atau 
tidak adanya trust. Dalam kehidupan bersama, kemampuan dan keinginan untuk melihat perbedaan antar suku bukan sebagai yang memisahkan di dalam kehidupan dan pergaulan sehari-hari bahkan lebih mempererat dan memperjaya kehidupan dan kebudayaan nasional. Arttinya bahwa menurut Buchori (H.A.R Tilaar, 49: 2011) bahwa pendidikan adalah sarana transformasi budaya. Lebih lanjut buchori mengatakan Pendidikan bukan semata-mata sekedar berfungsi sebagai transmisi kebudayaan-kebudayaan yang ada, tetapi mempunyai fungsi untuk menilai dan memilah-memilih apa saja di dalam kebudayaan sebagai peninggalansejarah hidup manusia dapat digunakan dalam menghadapi perubahan sosial dalam era globalisasi.

\section{E. SIMPULAN DAN SARAN}

Perkembangan zaman menuntut perubahan dalam berbagai dimensi dalam kehidupan dan begitu juga dengan pendidikan. Sejalan dengan perkembangan pendidikan abad 21 memberikan tantangan terhadap dunia pendidikan kita untuk dapat mengembangkan berbagai kompetensi bagi peserta didik. Seiring dengan perkembangan juga memberikan sejumlah dampak yang perlu kita pikirkan mengenai dampak positif dan negatifnya.masuknya era digital mengalihkan pandangan anakanak kita meninggalkan berbagai hal bernuansakan nilai budaya. Ini perlu disikapi dan perlu campur tangan pendidikan untuk memberikan pandangan bahwa mengikuti perkembangan zaman memanag tidak bisa dielakkan, namun demikian nilai-nilai luhur harus ditanamkan dalam jiwa generasi penerus bangsa agar menjadi bangsa yang mempunyai nilai-nilai luhur berbasis kebudayaan namun juga mengikuti perkembangan zaman.

\section{DAFTAR PUSTAKA}
Abidin,
Y.(2015)
"Pembelajaran
Multiliterasi: Sebuah Jawaban

atas Tantangan Pendidikan

Abad Ke-21 dalam Konteks

Keindonesiaan". Bandung: PT

Refika Aditama.

Dewantara, Ki Hadjar. (1962). "Karja I

(Pendidikan), Jogjakarta:

Majelis Luhur Persatuan

Taman Siswa.

Dewantara, Ki Hajar (1964) "Asas-asas dan dasar-dasar Taman Siswa (Cetakan Ketiga). Yogyakarta: Majelis Luhur Persatuan Taman Siswa

Dewantara, Ki Hajar (1977). "Bagian Pertama: Pendidikan.

Yogyakarta: Majelis Luhur Persatuan Taman Siswa.

Dewantara, Ki Hajar (2009). "Menuju Manusia Merdeka", Yogyakarta: Leutika.

Dwiarso. Ki Priyo, Sistem Among Mendidik Sikap Merdeka Lahir dan Batin, dalam www.tamansiswa.org, diakses pada tanggal 2 pebruari 2012 .

Dyer, Jeffrey H. Gregersen, Hal B., and Christensen, Clayton M. (2009) The innovator 's DNA, Harvard Business Review, December 2009, pp. 110.

Grant Wiggins dan Jay McTighe. (2012).

Pengajaran Pemahaman

Melalui Desain. Jakarta: Indeks.

H.A.R Tilaar. (2007). MengIndonesia Etnisitas Dan Identitas Bangsa Indonesia: Tinjauan Dari Perspektif Ilmu Pendidikan. Jakarta: Rineka Cipta.

H.A.R Tilaar dkk. (2011). Pedagogic Kritis: Perkembangan Substansi, 
Dan Perkembanganya DI Indonesia. Jakarta: Rineka Cipta.

H.A.R. Tilaar (2012a). "Perubahan Sosial dan Pendidikan: Pengantar Pedagogik Transformatif Untuk Indonesia". Jakarta: Rineka Cipta.

H.A.R Tilaar. (2012b). Standarisasi Pendidikan Nasional: Suatu Tujuan Kritis. Jakarta: Rineka Cipta.

Koentjaraningrat. (1985). Kebudayaan Mentalitas Dan Kebudayaan. Jakarta: Gramedia.

Muthoifin. (2015). "Pemikiran Pendidikan Multikultural Ki Hadjar Dewantara". Jurnal Intizar, Vol. 21, No.2, 2015: Institut Agama Islam Surakarta Indonesia.

Rohman, Saifur \& Wibowo, Agus. (2016) "Filsavat Pendidikan Masa Depan: Kajian Filsavat Pendidikan Masa Depan" Yogjakarta: Pustaka Pelajar.

Panjaitan, dkk (2014) : "Pengertian Kebudayaan, Unsur-Unsur Kebuadayaan, Wujud Kebudayaan, dan Perubahan Kebudayaan". Tersedia [ONLINE] di https://coretanandrea.wordpres s.com/2013/11/03/definisikebudayaan-menurutbeberapa-ahli/

Subekti, Nanang Bagus (2015) "Memaknai Kembali Konsep Pendidikan Ki Hadjar Dewantara" Tersedia [ONLINE] https://nasional.sindonews.com /read/980100/162/memaknaikembali-konsep-pendidikanki-hadjar-dewantara$\underline{1427086654 .}$
Trilling, B dan Fadel, C. (2009) "21st Century Skills Learning For Life In Our Times". USA: HB Printing. 